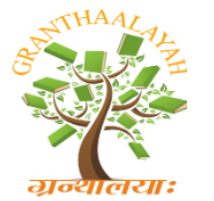

$$
\begin{gathered}
\text { INTERNATIONAL JOURNAL OF RESEARCH - } \\
\text { GRANTHAALAYAH } \\
\text { A knowledge Repository }
\end{gathered}
$$

Science

\title{
ORAL INJURIES IN A PATIENTE WITH HUMAN IMMUNODEFICIENCY VIRUS (HIV) INFECTION: A CASE REPORT
}

\author{
Talita Alves de Souza *1, Thamires Rodrigues Guedes *1, Érica da Silva Carvalho *2, Ângela \\ Xavier Monteiro ${ }^{* 2}$, Tirza Almeida da Silva ${ }^{* 3}$, Eduardo Jorge Sant' Ana Honorato *2 \\ ${ }^{*}$ School of Health, Uninorte, Brazil \\ ${ }^{* 2}$ School of Health, Amazon State University, Brazil \\ ${ }^{* 3}$ Psychology Department, UNIP, Brazil
}

\begin{abstract}
The first cases of Acquired Immunodeficiency Syndrome (AIDS) were reported in 1981 in patients with a high decline in immune response. Human immunodeficiency virus (HIV) infection can manifest itself through various signs and symptoms. The oral cavity is an extremely important way for diagnosis and prognosis, because oral lesions may present as clinical signs of disease progression or ineffective antiretroviral treatment. The objective of this study was to evaluate, diagnose and intervene in the oral lesions present in a patient with HIV infection. A case report study was conducted on a patient treated at the Dr. Antônio Comte Telles Polyclinic (Specialized Assistance Service for HIV / AIDS) in Manaus, Amazonas, Brazil. Lesions found in the patient were Leukemia, Smoker's Melanosis and Oral Candidiasis, the latter being treated with tongue hygiene and application of VegelipR associated with laser therapy. It was observed that the treatment was effective and in five sessions there was improvement in the lesion. Oral manifestations are closely related to the HIV virus, since they may be associated with infection and / or disease progression, indicating deficiency in the immune system, as well as interruption of antiretroviral treatment. Candidiasis is an opportunistic infection that, if properly diagnosed and treated, contributes to the improvement of the immune system. It is concluded that the knowledge of the dentist regarding the pathologies and their manifestations is important, as well as a multidisciplinary work in the reference centers for HIV. Keywords: HIV, AIDS, Oral Injury, Dentistry.
\end{abstract}

Keywords: AIDS; Dentistry; HIV; Oral Injury.

Cite This Article: Talita Alves de Souza, Thamires Rodrigues Guedes, Érica da Silva Carvalho, Ângela Xavier Monteiro, Tirza Almeida da Silva, Eduardo Jorge Sant' Ana Honorato. (2019). "ORAL INJURIES IN A PATIENTE WITH HUMAN IMMUNODEFICIENCY VIRUS (HIV) INFECTION: A CASE REPORT." International Journal of Research - Granthaalayah, 7(8), 1-8. https://doi.org/10.29121/granthaalayah.v7.i8.2019.632. 


\section{Introduction}

In 1981 in the United States of America, the first cases of Acquired Immunodeficiency Syndrome (AIDS) were reported in homosexual male patients who had a high decline in immune response, related to the onset of several cases of Pneumocystis carinni pneumonia and Sarcoma. Kaposi, characterizing the syndrome according to the Centers for Disease Control and Prevention (CDC) as a disease' ${ }^{1}$.

The Human Immunodeficiency Virus (HIV) is a retrovirus of the family Retroviridae and genus Lentivirus that affects the cells of the immune system, destroying macrophages, dentitic cells and mainly CD4 + T lymphocytes. After HIV infection, some clinical manifestations are observed, such as fever, malaise, which are initial manifestations, disappearing within a few days into the latency period, which leads to a decrease in CD4 + T cells in the lymphoid tissues and consequently tissue destruction.

In the blood, the CD4 + T cell count decreases and may drop below 200 per $\mathrm{mm}^{3}$, in which case the patient has immune deficiency, becoming susceptible to infections and opportunistic diseases are classified as AIDS. Attempting to defend the body becomes ineffective because the response of the immune system to HIV eventually spreads the infection².

Oral manifestations can often lead to the initial diagnosis of HIV as they result from compromised immune systems and studies indicate that oral lesions can occur in more than $50 \%$ of patients with HIV / AIDS. The oral cavity is an important source of information for the diagnosis and prognosis of diseases associated with HIV infection, and are among the first clinical signs of infection or may predict its progression to AIDS. Oral manifestations may be caused by bacteria, fungi and viruses, or neoplastic in nature, clinically present as hairy leukoplakia, oral candidiasis, linear gingival erythema, kaposi sarcoma, necrotizing ulcerative gingivitis and necrotizing ulcerative periodontitis ${ }^{3}$.

Numerous fungal infections affect the oral cavity, the most common being candidoses, specifically Candida and Candida albicans ${ }^{4}$. Candidiasis manifests itself in a variety of forms, the pseudomembranous form being the most common, clinically presenting as white, creamy, detachable plaques. located in the jugal mucosa, tongue and palate ${ }^{5}$. The aim of this article was to report a clinical case of oral manifestations in a patient with HIV infection.

\section{Method}

The research project was submitted to the Medical Ethics Committee of the Amazonas State University - School of Health Sciences and approved on 07/31/2015 under CAAE number 43228914.0.0000.5016. A case report was performed on a patient treated at the polyclinic Dr. Antônio Comte Telles - (Specialized Assistance Service in HIV / AIDS), diagnosed with HIV / AIDS infection.

The inclusion criterion was a patient diagnosed with HIV / AIDS infection, of both sexes and over 18 years of age, under follow-up at the Dr. Antônio Comte Telles clinic. The exclusion criterion was not being able to participate patients who besides being HIV positive had a diagnosis of diabetes, cancer, autoimmune diseases and drug addicts. 
The patient who met the inclusion criteria was invited to participate in the study. The one who accepted, received the information about the study and signed the free and informed consent form. A complete dental examination was performed. The patient participating in the project was examined for manifestations of oral lesions for further diagnostic hypothesis and treatment. For this exam, a flat mouth mirror number 5, wooden spatula, gauze, tongue sanitizer was used. From the observed lesions, the treatment protocol was started.

\section{Case}

A 35-year-old male patient with HIV infection presented to the Dr. António Comte Telles Polyclinic for medical follow-up and subsequent dental evaluation.

The anamnesis was performed investigating the odonto-stomatological history, past history and habits. The patient reported having the HIV virus for 8 years and taking the drug (Zidovudine / Lamivudine $300 \mathrm{mg} / 150 \mathrm{mg}$ and Lopinavir / Ritonavir $200 \mathrm{mg} / 50 \mathrm{mg}$ ).

Viral load of 466,142 copies / $\mathrm{ml}$ (high viral load - 100,000 to 1 million copies / $\mathrm{ml}$ ) was considered high viral load and CD4 lymphocyte count 231 cells / mL, which approximates the rate to be considered evolution to AIDS, CD8 1,477 cells / $\mathrm{mL}$, factors that predispose the appearance of these lesions (normal CD4- 500-1,612 cells / mL).

As a habit, the patient reported being a smoker since his teenager years, smoking up to 10 cigarettes a day. The clinical examination revealed asymptomatic white lesions formed by detachable pseudomembranous edges, with a rough surface located throughout the tongue, including the right lateral border and the presence of a coating (Figure 1). At jugal mucosa, bilaterally it was observed

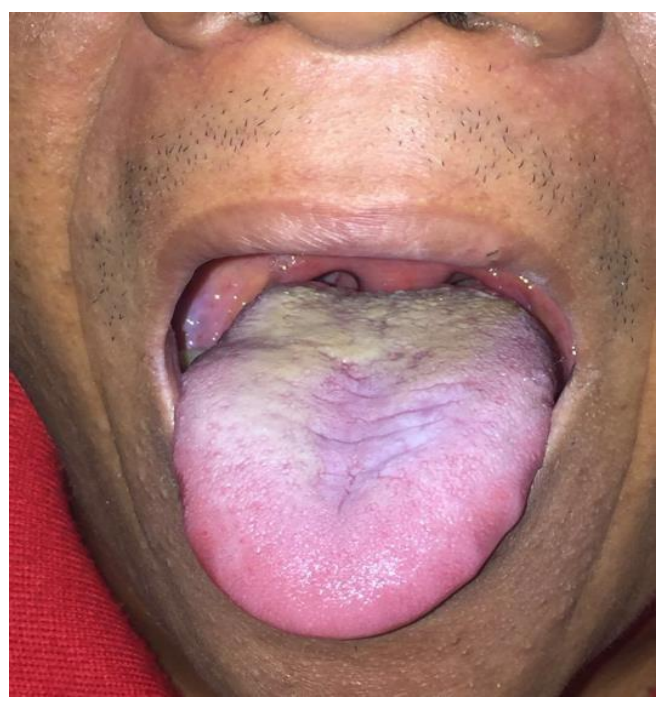

Figure 1: Asymptomatic white lesions formed by pseudomembranous edges located throughout the tongue.

At jugal mucosa, bilaterally there were diffuse whitish streaks along with brownish spots (Figure 2 A, B). And bilateral parotid gland enlargement. Absence of dental elements: 17, 26, 38, 37, 47 and 44. The diagnosis was based on clinical signs, where there was a predominance of coating, bleeding cleft, candidiasis on tongue surface lesions. 
Whitish striae diagnosed as leukoedema and smudges as smokers' molasses were found in the University Polyclinic by a pathologist. It was decided not to undergo treatment for smokers' leukoedema and melanosis, because leukoedema is considered a variation of normality, with no known etiology. Smoker's melanosis, by the only way to be interrupting the smoking habit.

As a treatment for candidiasis, in the first session, intra-oral cleaning with $0.12 \%$ alcohol-free chlorhexidine digluconate and a wooden spatula scrape were performed, where part of the crust installed on the tongue was removed. (Figure 3).

From the second session, the intervention was performed with a topical manipulated paste containing: Vegelip 10\%, Triancionoloma 1mg, Aciclovir 50 mg / 1g, Nystatin 25000UI / 1g, Orabase QSP 1g.

Along with the use of the paste, the low intensity laser therapy was used, with beam area of approximately $0.05 \mathrm{~cm}^{2}$ with wavelength $660 \mathrm{~nm}$, power $\mathrm{x}$, energy density $3 \mathrm{~J} / \mathrm{cm}^{2}$ and application of thirty seconds per point, without contact with the lingual surface and one minute pause in each shot three times (Figure 4). The patient received a daily visit, over a period of five days, totaling five sessions, resulting in the improvement of the stomatological condition (Figures 5 and 6).

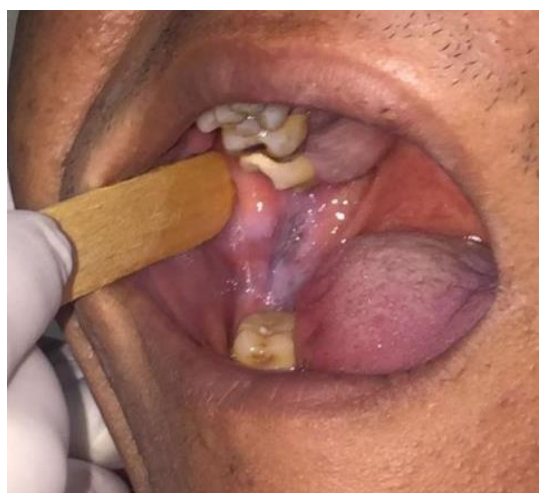

Figure 2A: Whitish stretch marks on the right jugal mucosa and brownish spots

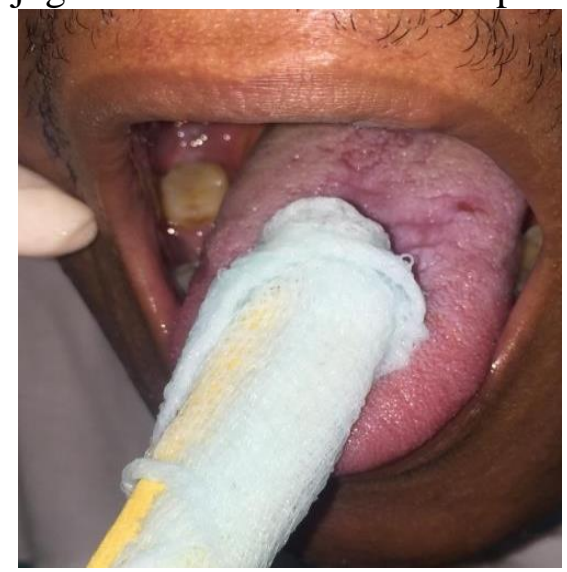

Figure 3: 1st session, tongue hygiene with $0.12 \%$ chlorhexidine digluconate.

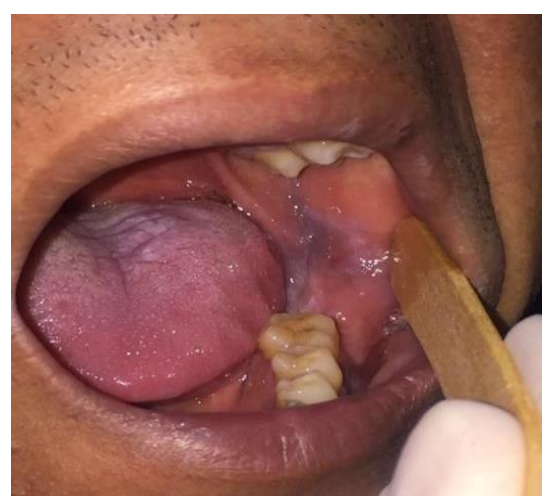

Figure 2B: Whitish stretch marks on the left jugal mucosa and brownish spots

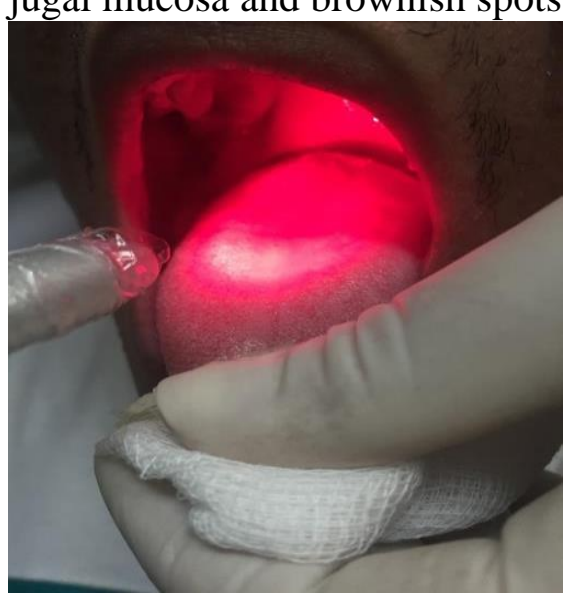

Figure 4: 2nd session, laser therapy after topical application of Vegelip 


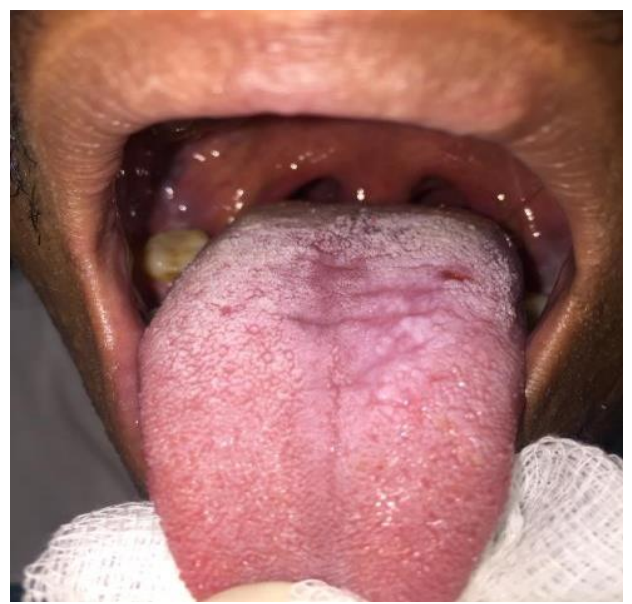

Figure 5: 4th session after topical application of VegelipR and laser therapy.

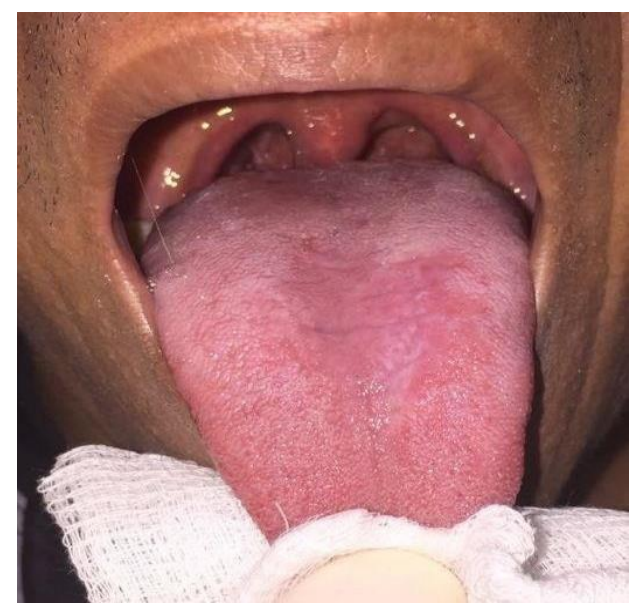

Figure 8: 5th session, where significant improvement was observed in relation to the initial picture.

\section{Conclusions and Recommendations}

Manifestations of HIV infection are opportunistic and may affect the neck, head, and oral cavity, including diffuse reactive adenopathy. Some mouth lesions are characteristic of HIV infection such as oral candidiasis, a fungal lesion that is the most common in HIV seropositive patients. Oral lesions strongly associated with CD4 + count and viral load are considered clinical markers of HIV viremia and destruction of the immune system with disease progression ${ }^{6-18}$.

The frequency of oral candidiasis in HIV-positive patients can reach up to $94 \%$ of subjects according to the stage of infection. A retrospective epidemiological study that consisted of 431 medical records of HIV patients treated at the Stomatology Service of the Hospital Heilópolis-São Paulo, showed that oral manifestations were not present only in $25.52 \%$ of the evaluated ${ }^{7}$.

This shows the high prevalence of oral lesions in seropositive patients. Candidiasis and hairy leukoplakia may be related to CD4 + cell count and viral load in HIV-positive patients, indicating them as clinical markers of disease progression. In a study of 124 patients with HIV-positive serology who were not on antiretroviral treatment, a decrease in CD4 + cells and an increased viral load was observed, of which 18 patients developed oral lesions. 11 with oral candidiasis and 7 with hairy leukoplakia, the others had no lesions. CD4 + cell count and viral load are the tests that best assess the risks of opportunistic infections and indicate progression to the syndrome $e^{8-9-14}$. Thus explaining the reason for the present manifestation.

One study identified the prevalence of oral lesions in AIDS patients at the Parthenon Sanatorium Hospital, relating CD4 + lymphocyte counts and CD8 + lymphocytes, where 42 patients at the Sanatorio Parteon Hospital over an 8-month period had oral manifestations ${ }^{10}$.

In all studies, the lesions caused by Candida are the ones that most manifested in HIV patients, varying their manifestation, showing the prevalence of Candidiasis. Injuries associated with herpes, oral candidiasis, and hemorrhages are lesions often associated with infection. In a study of 100 HIV-infected individuals undergoing treatment at the Amazonas Tropical Medicine 
Foundation (FMT-AM), a large occurrence of lesions resulting from pseudomembranous candidiasis was observed, followed by other infections and oral lesions such as gingivitis and periodontitistites $^{11-12}$.

Thus, it is perceived the need to guide the population on the appearance of oral lesions resulting from the virus so that treatment begins and consequently a drop in the number of deaths from the HIV virus. Minimal clinical examination is necessary to make a correct diagnosis, cause identification, and treatment, as there are several white lesions and numerous forms of clinical manifestations. Candidiasis is a fungal infection that is more closely related to the immune status of the individual. Clinically, there are detachable plaques or white nodules, which may be asymptomatic or not ${ }^{13-15}$.

In the present case report, there were no painful symptoms. It is noteworthy that in recent years, the social profile of HIV / AIDS infection has changed dramatically. With the innovations of antiretroviral therapy, there was an increase in the life expectancy of infected patients, as the treatment seeks to reconstruct the individual's immune system.

However, as an oral manifestation, oral candidiasis remains among the most prevalent lesions accompanied by hairy leukoplasty and papillomatous lesions. In countries where the practice of free and universal distribution of antiretroviral medication, there was a $50 \%$ decline in the prevalence of oral lesions ${ }^{16}$.

Showing the importance of treatment, which thus avoids oral manifestations. Due to the treatment in which patients are submitted, oral microbiota is favorable for the development of yeast species, including Candida. One study showed that 45 AIDS patients had symptomatology for Oral Candidiasis and the most commonly found form was erythematous and pseudomembranous ${ }^{17}$. Chlorhexidine's high antimicrobial activity makes it widely used for oral infections against various microorganisms, including Candida albicans, for its effectiveness at low concentrations good results and their ability to act for a long time ${ }^{19}$. After the first session, effective cleaning with 0.12\% alcohol-free Chlorixin Digluconate was observed.

The treatment with Vegel associated with laser therapy has shown results in a shorter time interval compared to studies with systemic medication and topical antifungals. Vegelip is an ointment developed by Prof. MSc. Lioney Noble Cabral- Prof. Pathologist at the State University of Amazonas-UEA, which contains Vegelip 10\% / 1g, Triancionoloma 1mg / 1g, Acyclovir 50mg / 1gm, Nystatin $25000 \mathrm{IU} / 1 \mathrm{~g}$, Orabase QSP 1g.

In relation to smoker's melanosis found in the patient, it is associated with the elements that constitute tobacco, especially nicotine. As tobacco consumption increases, melanin production ${ }^{21}$ is stimulated by melanocytes that adhere to nicotine, thus producing pigmentation. Treatment and prognosis consists of habit interruption, disappearing in approximately three years. When dealing with inappropriate areas, biopsy should be considered a treatment option.

We chose not to perform any treatment on the patient due to the location of the lesion. Leukoedema is a variation of normality, being more commonly associated to the smoking individual. Clinically, it presents with a diffuse whitish aspect, with a pleated surface, causing non-detachable whitish 
streaks, bilaterally. Its diagnosis is strictly clinical; it consists in extending the mucosa and the whitish aspect disappears ${ }^{22}$.

No treatment is required as it is a benign condition. Increased bilateral parotid gland volume is a common finding in HIV-positive patients, because a series of signs and symptoms expand to the head and neck region, and may or may not be associated with cervical lymphadenopathy. Treatment is done by fine needle aspiration (FNAB), which is a reliable diagnostic and treatment method $^{23}$. In the patient in question, the enlargement of the parotid gland was already present before confirmation of HIV infection and could be related to Epidemic Parotitis (more commonly known as mumps), untreated or poorly treated. May have got worse with HIV infection.

As an individual becomes infected with the human immunodeficiency virus (HIV) and progresses to acquired immunodeficiency syndrome (AIDS), the chances of the appearance of oral lesions are high $^{24}$ and prove the need for the presence of a Dentist in the infectious disease control, showing the importance of multidisciplinary.

Candidiasis is the most common manifestation in patients with HIV infection, and has a high diagnostic value because it can reveal the progression of the disease to AIDS, along with the test to evaluate viral load and count. CD4 T-cell. As shown in the case report, it is necessary knowledge from the Dentist Surgeon in view of the innumerable lesions that can manifest themselves, as well as their manifestations forms, for a correct diagnosis and elaboration of the treatment.

\section{References}

[1] Souza L. B, Pinto LP, Medeiros AMC, Junior RFA, Mesquita OJX. Manifestações orais em pacientes com AIDS em uma população bra- sileira. Pesq Odont Bras. 2000; 14(1): 79-85.

[2] Abbas AK, Lichtman AH. Imuno- deficiências Congênita e Adquiri- da: doenças causadas pelas respos- tas imunes defeituosas. In: Abbas AK, Lichtman AH. Imunologia Bá- sica. Funções e Distúrbios do Sis- tema Imune. Rio de Janeiro: Edito- ra Revinter; 2003. 213-228.

[3] Motta WKS, Nobrega DRM, San- tos MGC, Gomes DQC, Godoy GP, Pereira JV. Aspectos demográficos e manifestações clínicas bucais de pacientes soropositivos para o HIV/Aids. Rev Odontol UNESP. 2014; 43(1): 61-7.

[4] Mangueira DFB, Mangueira LFB, Diniz MFFM. Candidose Oral. R Bras Ci Saúde. 2010; 14(2):6972. Apud Silva CEXSR, Bornstein I. Candidíase Eritematosa: Relato de Caso Clínico. Rev. Odontol Univ Santo Amaro. 1998; 3(2): 77-9.

[5] Neville BW, Damm DD, Allen CM, Bouquot JE. Infecções Fúngi cas e Protozoários. In: Neville BW, Damm DD, Allen CM, Bouquot JE. Patologia Oral e Maxilofacial. 3a ed. Rio de Janeiro: Elsevier; 2009. p. 213.

[6] Silva SM, Pereira AL, Zapata MTAG. Manifestações bucais na infecção pelo Vírus da Imunodeficiência Humana: uma revisão sis- temática da literatura. Rev Fac Odontol. 2001; 52(1): 57-65.

[7] Cavassani VGS, Sobrinho JA, Ho- mem MGNH, Rapoport A. Candi- díase oral como marcador de prog- nóstico em pacientes portadores do HIV. Rev Bras Otorringolaringol. 2002; 68(5): 630-4.

[8] Milagres A, Ramos RT, Castiliano MH, Dias EP. Leucoplasia Pilosa Oral em paciente HIV positivo: Revisão de Literatura e Relato de Caso. J Bras Doenças Sex Transm. 2004; 16(2): 58-62.

[9] Miziara ID, Lima AS, Cortina RAC. Candidíase oral e Leucopla- sia Pilosa como marcadores de progressão da infecção pelo HIV em pacientes brasileiros. Rev. Bras Otorrinolaringol. 2004;70(3):310-4 
[10] Volkweis MR, Rocha RS, Leonar- do LN, Wagner JCB. Lesões Bucais manifestadas em pacientes aidéticos e tuberculosos, relacionadas com a contagem celular Cd4+/Cd8+. PGR- Pós Grad. Rev Fac Odontol. 2001;4(3):1-9

[11] Chagas MV, Santos LO, Ono LM. Manifestações Bucais de pacientes HIV atendidos na Fundação de Medicina Tropical do Amazonas (FMT-AM). Rev. Fac. Odontol. 2009;50(3):10-3.

[12] Gasparin AB, Ferreira FV, Danesi CC, Mendoza-Sassi RA, Silveira J, Martinez AMB, et al. Prevalência e fatores associados às manifestações bucais em pacientes HIV positivos atendidos em cidade sul-brasileira. Cad Saúde Pública. 2009;25(6):1307-15.

[13] Cruz MCFN, Garcia JGF, Braga VAS, Lopes FF, Pereira ALA. Le- sões Brancas da Cavidade Oral- Uma Abordagem Estomatológica. Rev. Fac. Odontol. Porto Alegre. 2009; 50(1): 5-8.

[14] Medeiros CF, Santos TB, Júnior RLCA, Moura SAB. Relação entre as manifestações estomatológicas, contagem de células CD4+ e carga viral em pacientes HIV positivos. Pesq Bras Odontoped Clin Integ. 2007; 7(3): 271-76.

[15] Miranzi MAS, Montandon DS, Mi- ranzi BAS, Meireles JF, Paula PB, Goulart DMM. Prevalência de ma nifestações bucais e sua associação com a infecção pelo vírus da imu- nodeficiência humana. Rev Enferm Atenção Saúde. 2015; 4(2):100-14.

[16] Noce CW, Júnior AS, Ferreira SMS. Panorama mundial da Epi- demia pelo HIV/AIDS: Aspectos sociais e Lesões bucais. J bras Do- enças Sex Transm. 2005; 17(4): 301-5

[17] Neves MIR, Nascimento MDSB. Aspectos Clínicos e Microbiológi- cos da Candidíase Oral em Pacien- tes com AIDS. Revista do Hospital Universitário/UFMA. 2001; (2): 20-25.

[18] Vieira TT, Sousa JP, Soares MSM, Lima EO, Paulo MQ. Candidose bucal em paciente HIV positivo: re- lato de caso. Rev. Odontol. Clin. Cient. 2012; 11(2): 169-171.

[19] Maekawa LE, Brighenti FL, Lam- ping R, Oliveira LD, Marcacci S, Koga-ito CY. Atividade antimicro- biana de enxaguatórios bucais sem álcool á base de Clorexidina sobre Candida albicans. Rev. Odontol Unesp. 2010; 39(1): 15-9. Apud Fardal O, Turnbull RS. A review of the literature on use of Chlorhexi- dine in dentistry. J Am Dent. As- soc. 1986; 112: 863-9. Apud Ep- stein JB. Antifungal therapy in oropharyngeal mycotic infections. Oral Surg Oral Med Oral Pathol. 1990; 69:32-41. Apud Zegarelli DJ. Fun- gol infections of the oral cavity. Otolaryngol Clin Nort Am. 1993; 26: 1069-89.

[20] Egg NOS, Castro CLS, Rodrigues FN, Cury VF. Melanose Racial e outras lesões pigmentadas da cavi- dade bucal- Revisão de Literatura. R. Periodonia. 2009; 19(3): 49-55.

[21] Neville BW, Damm DD, Allen CM, Bouquot JE. Lesões Físicas e Químicas. In: Neville BW, Damm DD, Allen CM, Bouquot JE. Pato- logia Oral e Maxilofacial. 3a ed. Rio de Janeiro: Elsevier; 2009. p. 287-330.

[22] Neville BW, Damm DD, Allen CM, Bouquot JE. Defeitos do De- senvolvimento da Região Bucal e Maxilofacial. In: Neville BW, Damm DD, Allen CM, Bouquot JE. Patologia Oral e Maxilofacial. 3a ed. Rio de Janeiro: Elsevier; 2009. p. 8-9.

[23] Stramandinoli RT, Cesa TS, Guis- tina JCD, Schussel JL, Pedruzzi PAG, Sassi LM. Paciente HIVpositivo com aumento de volume bilateral da glândula parótida: Rela- to de Caso. Rev Bras. Cir. Cabeça e Pescoço. 2011; 40(4):208-210.

[24] Costa DCB, Sarmento DJS, Silvei- ra EJD. Manifestações orais em pa- cientes HIV na era da terapia anti- retroviral de alta atividade: o que mudou? Uma atualização para o clínico. Int J Dent. 2001; 10(2): 97- 102.

\footnotetext{
*Corresponding author.

E-mail address: eduhonorato@ hotmail.com
} 